\title{
EVALUATION OF SELECTED ONLINE IMAGE-BUILDING ACTIVITIES BY POLISH UNIVERSITIES
}

\section{Agnieszka Marzęda}

University of Warsaw, Krakowskie Przedmieście 26/28, 00-927 Warsaw

agnieszka@marzeda.pl O ORCID: 0000-0003-2607-4123

\section{Dariusz Tworzydło}

University of Warsaw, Krakowskie Przedmieście 26/28, 00-927 Warsaw

dariusz@tworzydlo.pl O ORCID 0000-0001-6396-6927

DOl: 10.2478/minib-2021-0009

\section{ABSTRACT}

The purpose of this paper is to identify the online tools used by Polish universities and analyse to what extent these tools are used for image-related, communication, and marketing purposes. Based on our own analyses and desk research, we listed and then compared selected image-related activities carried out online by the higher education institutions rated as Poland's top universities in the "Perspektywy Ranking". We also extended our analysis to the universities rated as the world's top universities, selected based on the Webometrics ranking, and identified a clear difference in trends. The online tools listed in this paper were evaluated in terms of their impact on the position of the higher education institutions in the education market.

Key words: public relations, universities, marketing, new technologies, social media, students, communication, online 


\section{ABSTRAKT}

Celem artykułu jest wskazanie narzędzi internetowych używanych przez polskie uczelnie oraz stopnia ich wykorzystania w działaniach wizerunkowych, komunikacyjnych i marketingowych. Na podstawie przeprowadzonych badań i analiz desk research zestawiono, a następnie porównano wybrane działania wizerunkowe online prowadzone przez uczelnie uznane w rankingu Perspektyw za najlepsze w Polsce. Aby pokazać wyraźną różnicę w trendach, analizę wzbogacono o najlepsze uczelnie na świecie wyselekcjonowane na podstawie rankingu Webometrics. Narzędzia internetowe wskazane w artykule zostały poddane ocenie w zakresie ich wpływu na pozycję, jaką wybrane podmioty zajmują na rynku edukacyjnym.

Słowa kluczowe: public relations, uczelnie wyższe, marketing, nowe technologie, media społecznościowe, studenci, komunikowanie, online

JEL: 123

\section{Introduction}

Promotion has been one of the key elements of higher education management practically since the beginning of the changes initiated by Poland's democratic transition. Every year, demand for educational services is declining, limited on the one hand by the generally decreasing numbers of those aspiring to attend university and on the other by the generally increasing numbers of higher education institutions providing programmes adjusted to the changing reality. Universities are quickly trying to respond to these challenges by adapting their programmes and educational services to the needs of the job market and the changing economic landscape. 
Higher education institutions are therefore forced not only to analyse selected factors behind demand, but also to take into account the challenge posed by competitors. Declining birth rates have prompted universities to engage in strategic promotional planning, necessitating a search for various measures aiming to encourage potential students to explore the opportunities offered by higher education. Tools used by universities to enhance their competitive position include public relations, understood as the art of conducting dialogue with one's environment and fostering relations within an organization and outside of it (Tworzydło, 2017). Essentially, the purpose is to present a consistent image of an educational institution in keeping with its strategy and to facilitate proper communication between the institution and its environment (KaczmarekŚliwińska, 2006). One important distinguishing feature of public relations is two-way communication, which seeks understanding, acceptance, and cooperation between the organization and its environment (Gawroński, 2006). Bearing in mind the need to actively expand their knowledge about their environment and engage in professional communication, universities do not ask themselves if they need public relations, but perform broad analyses of the quality, professionalism, and effectiveness of the measures they take to convey information, build up their image, and promote their education services and the best practices in this field (Walkiewicz, 2005). In the context of the image of a higher education institution, we should consider such factors as information about its condition, the public image of its faculty members, students, and graduates, its involvement in the communities in which it operates, its relations with the media, the use of owned media (Kaczmarek-Śliwińska, 2013), and a range of other factors that impact on how the institution is ultimately perceived. As Waszkiewicz (2011) notes, "the image of a higher education institution depends on the overall perception of its functioning in terms of the roles it plays as a teacher, a creator of science and culture, a moral authority, an employer, a financially supported entity, an investor, and a means of transmitting power, together with the interpreted meaning of such perception and the resulting beliefs and attitudes". In addition, the image of a higher education institution is considered through the prism of its protection, especially in the context of potential crises that may threaten the stable functioning of 
the institution. Therefore, preparing for and adequately reacting to crises becomes crucially important for many organizations (Tworzydło, 2019).

The purpose of this paper is to identify online tools used by Polish universities and analyse to what extent these tools are used for imagerelated, communication, and marketing purposes. Since these activities impact directly on the reputation of every university, it appears crucially important to raise awareness of their importance, especially among those who are involved in higher education communication and marketing.

Since the arrival of the digital era, websites have been one of the first and most important tools for building the image of universities in their external and internal environment. A website serves not only as a university's online business card, but also as an interface facilitating various multidirectional interactions between the university and its environment (Szyfter, 2005). As a result of the rapid development of the Internet and the growing popularity of online communication, universities feel the need to highlight their online presence in a relevant way. It is no longer enough to have a basic website that has been designed for potentially interested members of the public and features very general content, often without regular updates. Growth in the number of Internet users has forced universities to ascribe greater importance to websites as channels of professional communication and design them as platforms for dialogue with their environment.

Universities are aware of the need to respond to the emergence of new tools and technological advancements and to explore the related opportunities, but also to assess the risks associated with such rapid development. The World Wide Web offers access not only to information about universities from all over the world and their programmes, but also to knowledge. Increasingly advanced technologies have made it possible not only to teach classes and carry out other important academic activities but also to create a network of connections with potential students and to convince them that they should choose a specific university as one that will guarantee the quality of education they expect. For higher education institutions, the new reality poses challenges in the area of not only education, but also other basic services they offer, in particular scientific research and research and development for the economy and the region (Hope, 2005). Necessitated by these new circumstances, the transformation 
of higher education institutions has been accelerated by the COVID-19 pandemic, which almost immediately forced many organizations, including universities, to take adaptive measures. The pandemic has led to changes in education, including teaching classes and handling relations with students as well as conducting research and promoting the effects of scientific work. Such changes would not have been so rapid if it had not been for the impulse provided by the outbreak of the pandemic, global lockdown measures, and local constraints.

However, using modern online tools and staying on top of modern trends and technologies gained significance in response not only to the pandemic but also to the findings of earlier analyses conducted by higher education institutions. University students are among those Internet users who test and use the latest solutions. This is one of the reasons why higher education institutions must to be present in the places frequented by its potential customers, and this also pertains to social media. Several of them are particularly relevant in this context. Among the Internet users, as many as $92 \%$ of those aged 18-24 declare that they maintain a presence in at least one form of such media (Feliksiak, 2016). The booming popularity of certain social media platforms has caused corporations, small businesses, non-government organizations (NGOs), and schools at various levels to notice the need to use such channels and the related benefits. In particular, social media support marketing activities, facilitate direct communication, and help shape one's public image (Buchnowska, 2013). They can be divided into six main categories: collaborative projects (such as Wikipedia), blogs and microblogs (such as Twitter), content communities (such as YouTube), social networking sites (such as Facebook), virtual game worlds (such as Warcraft), and virtual social worlds (such as Second Life) (Kaplan \& Haenlein, 2010; as cited in: Falahah \& Rosmala, 2012). From the perspective of their usefulness, the first four of these categories are by far the most attractive for universities. The popularity of such media continues to grow, for reasons that include: the possibility of reaching out to existing and future students, graduates, and employees, immediate feedback to the information posted and issues raised, the low cost of reaching recipients, and the possibility of surveying the views and opinions of those interested in or linked to a specific university. 


\section{Materials and methods}

For the purposes of this paper, we conducted a study in 2020 to analyse the activities carried out by selected universities using available online tools, the press offices of such universities, and their social media activity and websites, including video trends and direct communication (e.g. through online chats). In conducting our research, we used such tools as the SimilarWeb platform (https://www.similarweb.com). We identified and compared image-related measures taken by selected Polish universities. In order to highlight a clear difference in trends, we extended our analysis to cover some of the world's best universities, selected based on the Webometrics ranking (Ranking Web of Universities). We identified changes taking part in the model of managing the image of a higher education institution. In addition, we assessed the impact of generational changes and image-related activities on the choice of a university and presented the role of e-learning as a tool and modern form of communication and education.

In the main part of our project, we ultimately analysed 52 universities in Poland and 10 from other countries in Europe and in the world. The study therefore encompassed a total of 62 official websites of higher education institutions.

Using the method of website content analysis, we classified them based on the following variables: the number of ranking points, statistics on the number of visits and the time spent on a website, shares of direct and referral traffic, and the presence of the universities on specific social media. We also identified mobile applications operated by universities. Relevant calibration of the data allowed us to perform statistical analysis. The principal analytical axis was formed by correlation analyses performed using the Pearson correlation coefficient. We also performed a classical frequency analysis with a percentage frequency distribution. Additionally, analysing the time spent on a website implied the necessity of implementing the procedure of comparing means. It was assumed that significant differences would exist for the p-value of less than 0.05 (based on ANOVA). 


\section{Results}

Modern-day universities use numerous tools allowing them to reach out to selected target groups. Social media currently rank among the most powerful of such tools. Importantly, having a profile on such a platform as Facebook is as natural as having a website. In turn, having a website and updating it regularly is beyond dispute. In this case, the analysis of the collected research material showed that the number of points that universities in Poland had in the "Perspektywy Ranking" (the country's most prestigious such ranking - Perspektywy Education Foundation, 2019) correlated strongly with the number of website visitors. The value of the Pearson correlation coefficient was 0.774 , and the correlation was positive. In other words, the more points a university had, the more visits to its website were recorded.

Importantly, Polish universities could obtain a maximum of 100 points in the Perspektywy Ranking. Since the lowest result was around 39 points, we could divide the sample into three proportional groups: the universities with a low level of points (between 39 and 59.3 points) accounted for $79 \%$ of the sample, those with a moderate level of points (between 59.4 and 79.7 points) constituted $15 \%$ of the sample, and finally those with a high level of points (between 79.8 and 100 points) comprised $6 \%$ of the higher education institutions under analysis. In this context, we can talk about a considerable disproportion in the points-based assessment (most universities ranked low in terms of points) with a clear dominance of the three highest-ranking universities: the University of Warsaw, the Jagiellonian University, and the Warsaw University of Technology. In 2020, the situation was very similar, with the same three universities claiming the top three spots in the Perspektywy Ranking - the only difference being that the Jagiellonian University ranked first.

Bearing in mind the data obtained in the course of our research, we analysed the frequency of website visits, among other things. We arrived at the general conclusion that the number of Internet users visiting the websites of Polish universities had grown steadily in the six-month period 
Chart 1. Change in the number of visits to the websites of Polish universities over the sixth-month period under study $(\mathrm{N}=51)$

A RISE BY OVER $41 \%$

A RISE BY $31-40 \%$

A RISE BY $21-30 \%$

A RISE BY $11-20 \%$

A RISE BY $1-10 \%$

A DECLINE IN THE NUMBER OF VISITS

\section{4}

6

9

4

\section{5}

3

Source: the authors' own compilation.

under study. The statistics were collected in June 2020 and covered the months from December 2019 to May 2020. We observed a downward trend for only three universities (6\% of the sample), namely the Medical University of Eódź, the University of Agriculture in Kraków, and the University of Life Sciences in Lublin. Importantly, one in five universities from the Perspektywy Ranking recorded a rise of at least $30 \%$ in the number of visits (19.6\% of the sample). This resulted from the changes in the overall situation in the world, including the approach to searching for and using information. People are growing increasingly likely to use the Internet and explore the opportunities offered by modern technologies higher education institutions also react to such changes. Those responsible for marketing at universities realise that this trend will continue and know that for higher education institutions the future of promotion is online. A website is therefore not merely a window to the world. Content posted on websites and the ways in which it is presented must meet the ever-growing requirements of today's world, with the rising complexity of the information shared by universities with their 
environment highlighting the need for its relevant visualization and presentation.

Our research shows that users spent an average of nine minutes when visiting the website of a university listed in the Perspektywy Ranking (mean $=9.04 \mathrm{~min}$ ). Based on the time values, we did not observe increases or decreases in the time spent on a website depending on such variables as the number of points in the ranking or the number of visitors. From the perspective of the given university, of course, the time spent on its website is an important parameter. The longer a potential candidate stays on the website, the more likely this person is to find the content of this website useful. We can therefore assume that as the time spent on a website grows, so does the knowledge of its visitors and the chance that they will retain information that will later influence their decisions, for example regarding their ultimate choice of university.

Based on a detailed analysis of the datasets, we found no correlation between the number of visitors and the number of pages they viewed. This may also mean that the Internet users visiting university websites know exactly what they are looking for and do not waste their time on general browsing. Also, it can be assumed that potential recipients go directly to the information they are searching for. Examples may include admissions (for potential students) and job vacancies (for potential employees). This only serves to confirm the significance of a clear and logical layout of the websites of the universities under study. On the other hand, as we have already stated, the average time spent on a website is fairly long, which may mean that visitors read the content posted there relatively carefully.

When analysing the data we had obtained, we noted an interesting correlation: the more points a university had in the Perspektywy Ranking (Perspektywy Education Foundation 2019), the larger the share of visits by users from countries other than Poland ( $r=-0.329 ; p=0.018 ; n=51$ ). This means that having a good reputation enables a university to attract the attention of not only Polish, but also foreign visitors, who browse the content posted on its specific pages. To follow this line of thinking, we should note that the highest-ranking universities actively reach out to such candidates or indirectly attract the interest of those planning to study in 
Poland. On the other hand, the number of users visiting the websites under study correlates positively with the share of direct traffic. This means that the higher the number of visits, the larger the share of direct visits resulting from users typing the website's URL into a browser (i.e. not via any referring website) $(r=0.347 ; p=0.012 ; n=52)$. The universities that take up the top spots in the Perspektywy Ranking are sufficiently recognizable, and this recognizability is strong enough for users to find the websites of such universities directly, without using for example the Google search engine. This points to the proper positioning of these universities, but also indicates that they have worked very hard for years to build their image and online presence.

Growth in the number of visits to the websites of the Polish universities featured in the Perspektywy Ranking also correlates strongly with the number of pages per visit. We noted that the higher the percentage increase in the number of visits in the six-month period under study, the higher the average number of pages per visit $(r=0.592$; $p=0.001 ; n=51$ ). If Internet users choose to type the website's URL directly into a browser (direct traffic), the average number of pages per visit changes significantly. We observed that the higher the percentage share of such direct traffic, the higher the average number of pages per visit $(r=0.749 ; p=0.001 ; n=52)$. Here, we can talk about informed visitors who type in the address of a website they know and then browse it carefully. On the other hand, the higher the percentage share of referral traffic, the lower the average number of pages per visit $(r=-0.323 ; p=0.019 ; n=52)$. Here, we can talk about more random visitors, which should not be taken to mean that they are less important. In the context of the websites under analysis, we can generally conclude that informed visitors outnumber greatly random visitors (the average share of the former group is around $47 \%$, compared with less than $2 \%$ for the latter group). Informed visitors determine the percentage rise in the number of visits over the six-month period under study. The higher the percentage share of type-in traffic, the greater the aforementioned percentage increase $(r=0.427 ; p=0.002 ; n=51)$.

In general, one group of Internet users consists of those who type in the address of the website directly into a browser (representing a $47.4 \%$ share 
of the whole sample). Here, the relatively largest share was recorded for the Medical University of Gdańsk and the smallest for the SWPS University of Social Sciences and Humanities in Warsaw (74\% and 24\%, respectively). The second most frequent group of visitors is formed by those who find university websites using search engines (representing a $44.1 \%$ share of the whole sample). The largest share was noted in the case of the Adam Mickiewicz University's website (72\%), while the lowest share was recorded for the Medical University of Gdańsk (18\%). An average of $5.4 \%$ users reach the websites of Polish universities via their social media profiles. Here, the top position is occupied by the Adam Mickiewicz University (19\%), while the relatively lowest result was achieved by the University of Białystok (2\%). Internet users accessing websites through various types of referring websites account for $1.9 \%$ of all visitors (as many as $13 \%$ access the website of the Warsaw School of Economics in this way). Other sources of traffic account for a marginal percentage share of all the results obtained.

For $49 \%$ of the universities in the Perspektywy Ranking, the Internet users visiting their websites are dominated by those who type the website addresses directly into their browser address bars. An equally large share of Internet users (51\%) rely on search engines. The former group visits a significantly higher number of pages per visit (an average of 8.6 compared with 6.2 for those using search engines) (ANOVA, where $F=14.918 ; p=0.001$ ). The average time spent on a website by users typing that website's address directly into a browser is 9 minutes and 15 seconds. For those who access the website from search engine results, this period is comparable (9 minutes and 11 seconds). Likewise, we found no significant differences in terms of the number of points in the Perspektywy Ranking (56 points for universities whose websites are dominated by direct traffic, compared with 53 points for the search engine group).

Finally, it is worth noting the distribution of countries (other than Poland) from which Internet users visit the websites of top Polish universities. The leader in this respect is Ukraine (21.6\% of all cases), followed by Germany and the United States (11.8\% each), Belarus and Sweden (7.8\% each), and finally Spain and the UK (3.9\%). 


\section{Leading Polish universities against world universities}

We extended our analysis to include a comparison of Polish universities against top five universities in the world and in Europe, treating them as a reference group. One of the world's most popular university websites is the website of Harvard University (https://www.harvard.edu), which was visited in the peak month (October 2020 ) by over 55 million users. It is followed by the websites of the Massachusetts Institute of Technology (https://www.mit.edu) with 49.04 million users and Stanford University (https://www.stanford.edu) with 24.34 million users. During the period under analysis, we noted significant differences in terms of website reach. During the first six months of 2020, interest in the website of the university widely regarded as the world's best (Harvard) dropped by nearly $17.5 \%$ (see the table below), only to return to its previous level a few months later. This fact is linked not only to the academic year, but also to the period of the coronavirus pandemic, which necessitated remote learning.

Statistics for Polish universities show a somewhat different trend. While the number of visits to the websites of the world's top universities fell, Polish websites gained in popularity. With an average rise of $20.16 \%$, the universities that recorded growth in the number of visits included the Medical University of Gdańsk, the Medical University of Lublin, and the Medical University of Silesia (their popularity increasing by 50\%). Importantly, the universities that reported the highest growth are associated with education in various areas of medicine, which may point to the emergence of a trend among those deciding on their future education. 
Table 1. Changes in the category of website visits

\begin{tabular}{|c|c|c|c|}
\hline University & $\begin{array}{c}\text { World } \\
\text { rank }\end{array}$ & $\begin{array}{c}\text { Number of } \\
\text { visits (in million) }\end{array}$ & $\begin{array}{c}\text { Rise over } \\
\text { six months (\%) }\end{array}$ \\
\hline \multicolumn{4}{|c|}{ Universities in the world } \\
\hline Harvard University & 1 & 49.04 & $-17.48 \%$ \\
\hline Stanford University & 2 & 25.14 & $-5.32 \%$ \\
\hline Massachusetts Institute of Technology & 3 & 43.75 & $-2.50 \%$ \\
\hline University of California, Berkeley & 4 & 15.81 & $-14.75 \%$ \\
\hline University of Washington & 5 & 11.50 & $-0.10 \%$ \\
\hline \multicolumn{4}{|l|}{ Universities in Europe } \\
\hline University of Oxford & 6 & 8.72 & $8.74 \%$ \\
\hline University of Cambridge & 7 & 7.64 & $-0.24 \%$ \\
\hline University College London (UCL) & 8 & 5.72 & $4.45 \%$ \\
\hline Swiss Federal Institute of Technology (ETH Zurich) & 9 & 6.52 & $12.19 \%$ \\
\hline University of Edinburgh & 10 & 4.23 & $0.80 \%$ \\
\hline \multicolumn{4}{|c|}{ Universities in Poland } \\
\hline University of Warsaw & 373 & 2.32 & $19.75 \%$ \\
\hline Jagiellonian University & 381 & 2.95 & $13.52 \%$ \\
\hline AGH University of Science and Technology & 517 & 3.73 & $12.96 \%$ \\
\hline Warsaw University of Technology & 534 & 2.43 & $21.75 \%$ \\
\hline Adam Mickiewicz University & 589 & 1.83 & $11.49 \%$ \\
\hline
\end{tabular}

Source: the authors' own compilation based on Webometrics.info, data for May 2020.

\section{Universities in social media and their communication activities}

A study conducted in 2012 showed that "universities have noticed not only the possibility but also the necessity of using social media in the process of scientific communication. Some of these institutions, especially those regarded as the most active, understand the need to diversify their communication channels" (Kulczycki, 2012). This leads us to the conclusion that universities have been working for years to achieve their current position, not only by conducting observations and performing analyses but also by actively responding to changes, including those taking place in communication technologies. Social media can be used not only as 
a communication platform, but also as a gateway to the places where the attention of the audience can be drawn for longer, namely websites. The analysis of the data we collected shows that the traffic generated by social media varies between $2.04 \%$ and $11.54 \%$ (an average of $5.4 \%$ ). One exception is the Adam Mickiewicz University - as much as $19.12 \%$ of referrals to the university's website come from social media, but no further and detailed data are available in this respect.

Analyses show that all Polish universities have profiles on both Facebook and YouTube, and a vast majority of them have both official and unofficial accounts, in addition to running private groups. Students themselves also have private groups and use instant messengers, chiefly Messenger and WhatsApp. Both modern trends and the popularity of websites prompt universities to explore new tools that offer growing possibilities for acting effectively and supporting students and lecturers.

Facebook is by far the most popular social medium used by universities, generating an average of $70 \%$ of referrals from social media. YouTube ranks second with an average of $24.92 \%$. However, we should note that the discrepancies are much greater here because some universities use this tool only to a small extent, whereas in the case of other universities, such as the Częstochowa University of Technology, the University of Gdańsk, and the Medical University of Gdańsk, YouTube generates 40-45\% of all traffic from social media to the university website. Fewer than twenty universities have decided to set up accounts on LinkedIn, but the traffic generated in this way is essentially negligable (around $1 \%,+/-0.5 \%$ ), the only exception being the Lublin University of Technology (9.01\%). If we look at this situation from the perspective of the changes taking place in the use of this tool in communication, especially in business communication, we may both presume and assume that universities will be further exploring this communication channel, in particular by looking for opportunities to communicate information about such projects as postgraduate or MBA studies.

The statistics related to the use of Twitter as a microblog, or a medium focused on presenting the latest political, sports, business and other news, are extremely interesting. One may conclude that compared with global universities, Polish higher education institutions neglect Twitter in terms 
active use of this tool. This may be because they have failed to properly assess its potential. Among the 52 universities included in the study, 60\% have Twitter profiles. However, the use of this tool is noticeable and fairly regular only in the case of the Wrocław University of Environmental and Life Sciences (12.53\%), the John Paul II Catholic University of Lublin (7.67\%), the University of Szczecin (6.51\%), and the Medical University of Łódź (5\%). For the websites of the remaining universities, the traffic generated by Twitter ranges between $0 \%$ and $3.44 \%$ (an average of $0.7 \%$ ). Such results are very low compared with the popularity of the profiles of the world's best universities, which proves that Polish universities are only starting to notice the need for active presence on Twitter. Among education profiles, the most popular ones (in terms of the number of visits) are those run by British universities, specifically the University of Cambridge (19.98\%), the University of Oxford (19.71\%), and University College London (19.43\%), as well as by Harvard University (17.56\%) and Stanford University (16.25\%). Eight of the universities we studied use Research Gate, but only the University of Zielona Góra (6.51\%) does so in a noticeable way. Most of the universities also have their own IT systems for managing education processes, studies, and communication with students, typically a USOS or another system designed to meet specific requirements or needs.

To complement our research project, we performed a detailed analysis of the websites of the eight highest-ranking universities in the Perspektywy Ranking (Perspektywy Education Foundation, 2019) in terms of their communication activities. All of these universities have promotion offices, as well as press rooms, but the latter are not always properly visible. We observed that the materials for journalists vary in terms of quality and characteristics. In fact, only one university designed its press kit professionally and in keeping with the recommendations of public relations experts. Most of the information materials are available to all users of the university websites and form integral parts thereof. Photographs and videos are made available to the media as links or downloadable resources. Only three of the universities we analysed offer a newsletter only for journalists.

Importantly, all the higher education institutions we analysed have dedicated units responsible for communication. Most of them are headed by 
a press officer or the rector's plenipotentiary for communication or media relations. However, only one of the press officers has an official social media account, and one runs an official expert blog. On the other hand, all universities offer newsletter subscriptions to users of their websites. Websites feature attractive downloadable content, including logos, as well as links to social media, including less popular ones such as Flickr, Pinterest, and Goldenline (a Polish business-oriented social networking website). Despite many positive actions and activities of Polish universities, there are still many areas in which public relations and promotion could be addressed more professionally.

\section{Conclusions}

It is evident that the universities we analysed understand the potential that lies inherent in the Internet, and some of them draw their inspiration from foreign universities. However, they are as yet unable to fully respond to the measures being successfully taken by the world's most renowned universities. Observing the trends and processes taking place in the global education market is an important element of evolution and active participation. Changes in the sphere of promotion have been sped up by the COVID-19 pandemic, forcing universities not only to reflect on what is the norm for reputable universities interested in promotion but also to respond swiftly to changes in this field.

The changing market necessitates a comprehensive approach to promotion in higher education institutions. For reasons related to the widespread use of Internet tools, it is crucial not only to analyse the potential and opportunities created by technological advancements but above all to open up to novel solutions. Universities may benefit more from the effects of this approach if they engage to a greater extent in addressing promotion issues and exploring related opportunities systematically and openly. Systematically here refers to taking steps based on operational and strategic planning, while openness describes the approach to the implementation of new solutions and communication technologies. No university can afford to neglect to perform relevant analyses and implement the conclusions to be drawn from their findings. The websites 
of Polish universities prove to be a key element of their strategic and operational communication in the online world, in addition to being one of the most effective tools for building and fostering good relations between universities and their environment and for shaping their public image (Jędrych, 2015). Polish university websites vary greatly in terms of appearance, functionality, and content, which demonstrates their original approach to website design. Since Internet users visiting such websites look for relevant and appropriately profiled data, universities additionally need to devote more attention to information quality and website navigation.

Equally importantly, Polish universities should seek to attract the attention of those interested in studying in Poland. Such markets undoubtedly include Ukraine and other countries of the former Eastern Bloc. Universities must therefore focus on creating content tailored to the information needs of those who may be interested in the educational services they offer.

\section{References}

1. Buchnowska, D. (2013). Wykorzystanie mediów społecznościowych przez uczelnie wyższe i studentów w świetle badań własnych. Nauki o Zarzadzaniu, 2(15), 36-50.

2. Falahah \& Rosmala, D. (2012). Study of Social Networking Usage in Higher Education Environment. Procedia - Social and Behavioral Sciences, 67, 156-166. https:/doi.org/ 10.1016/j.sbspro.2012.11.316

3. Feliksiak, M. (2016, June). Komunikat z badań CBOS. Korzystanie z Internetu (No. 92/2016). Fundacja Centrum Badania Opinii Społecznej. https://www.cbos.pl/SPISKOM. POL/2016/K_092_16.PDF

4. Gawroński, S. (2006). Media relations. Wspótpraca dziennikarzy i specjalistów PR. Wydawnictwo Wyższej Szkoły Informatyki i Zarządzania.

5. Harvard University, www.harvard.edu. Retrieved May 2020.

6. Hope, E. (2005). Public relations uczelni, czyli szewc bez butów chodzi. In E. Hope (Ed.), Public relations instytucji użyteczności publicznej. Scientific Publishing Group.

7. Jędrych, E. (2015). Wykorzystanie mediów społecznościowych w zarządzaniu pracownikami w organizacjach gospodarczych. Zeszyty Naukowe Uczelni Vistula, 44(6), 120-132.

8. Kaczmarek-Śliwińska, M. (2006). Internet Public Relations uczelni publicznych w Polsce. Marketing i Rynek, 5, 31-35.

9. Kaczmarek-Śliwińska, M. (2013). Wizerunek szkoły w nowych mediach. In V. Korim \& R. Uździcki (Eds.), Szkoła w perspektywie jej realnych przeobrażeń. Zarzadzanie Kompetencje - Kreatywność. Wydawnictwo Adam Marszałek. 
10. Kaplan, Andreas \& Haenlein, Michael. (2010). Users of the World, Unite! The Challenges and Opportunities of Social Media. Business Horizons. 53. 59-68. 10.1016/j.bushor.2009.09.003.

11. Kulczycki, E. (2012). Wykorzystanie mediów społecznościowych przez akademickie uczelnie wyższe w Polsce. Badania w formule otwartego notatnika. In E. Kulczycki \& M. Wendland (Eds.), Komunikologia. Teoria i praktyka komunikacji (pp. 89-109). Wydawnictwo Naukowe Instytutu Filozofii UAM.

12. Massachusetts Institute of Technology, www.mit.edu. Retrieved May 2020.

13. Perspektywy Education Foundation. (2019). Ranking Szkót Wyższych Perspektywy 2019. Retrieved September 2020, from http://ranking.perspektywy.pl/2019

14. Ranking Szkół Wyższych Perspektywy, www.ranking.perspektywy.pl/2019/. Retrieved September 2020.

15. Ranking Web of Universities: Webometrics ranks, www.webometrics.info. Retrieved December 2020.

16. SimilarWeb Platform, www.similarweb.com. Retrieved December 2020.

17. Stanford University, www.stanford.edu. Retrieved May 2020.

18. Szyfter, J. P. (2005). Public relations $w$ internecie. Helion.

19. Tworzydło, D. (2017). Public relations praktycznie. Newsline.

20. Tworzydło, D. (2019). Zarzadzanie $w$ kryzysie wizerunkowym. Metody, procedury, reagowanie. Difin.

21. Walkiewicz, E. (2005). Public relations w działalności szkoły. In E. Hope (Ed.), Public relations instytucji użyteczności publicznej. Scientific Publishing Group.

22. Waszkiewicz, A. (2011). Wymiary wizerunku uczelni. In Wizerunek organizacji. Teoria i praktyka badania wizerunku uczelni (pp. 33-73). Oficyna Wydawnicza Aspra-JR.

Agnieszka Marzęda, - PhD, is an Assistant Professor at the Department of Journalism, Information and Book Studies at the University of Warsaw and an expert on communication. She has experience in management, PR and marketing. Publishing manager at London Wall Publishing. Expert for the National Centre for Research and Development (NCBiR), leader of the legislative group of the Sectoral Council for Marketing Communication and Secretary of Car of the Year Polska. Member of International Communication Association (ICA), the Polish Public Relations Association, the Polish Society of Social Communication and the Polish Scientific Society of Marketing.

Dariusz Tworzydło - PhD, DSc, is an Associate Professor at the University of Warsaw and an expert on Public Relations. President of the Association of Public Relations Agencies, and head of the Department of Social Communication and Public Relations at the Department of Journalism, Information and Book Studies at the University of Warsaw. Former President of the Polish Public Relations Association and member of the Public Relations Ethics Council. The author of more than 250 research articles, commentaries, reports, analyses, and expert studies. 